\title{
'n Alternatiewe formulier vir die bevestiging van dienaars van die Woord
}

\author{
M J du P Beukes \\ Emeritus-professor: Hervormde Teologiese Kollege \\ Universiteit van Pretoria
}

\begin{abstract}
An alternative formulary for the investiture of church ministers

This study aims to present an alternative formulary for the investiture of ministers in the Nederduitsch Hervormde Kerk van Afrika. The new formulary reflects the author's views that were initially outlined in part and verified by a number of church ministers and congregational members of the church. The article argues for the necessity of a rephrasing of existing formularies, given the current postmodern perceptions of the functions of the church over against the style of the current formulary. Current perceptions of the functions of ministers also necessitate an alternative formulary for the investment of church ministers.
\end{abstract}

\section{INLEIDING}

Sedert die sestigerjare van die vorige eeu is die Nederduitsch Hervormde Kerk van Afrika besig met die skryf van wissel-/alternatiewe formuliere. Op die Algemene Kerkvergadering van 1966 het wisselformuliere vir die doop, nagmaal en bevestiging van ampsdraers gedien. Hierdie vergadering het besluit dat verdere studie met betrekking tot die genoemde formuliere gedoen moet word en dat die kerk geleentheid moet kry om kommentaar op die genoemde formuliere te lewer.

In opdrag van die Kommissie van die Algemene Kerkvergadering het die kerk se Komitee vir Liturgiese Geskrifte die besluite van die Algemene Kerkvergadering ter hand geneem. Die skrywer van hierdie artikel het opdrag ontvang om in die besonder aandag te gee aan die formulier vir die bevestiging van dienaars van die Woord. Met die oog op evaluering en wysiging van die formulier wat op die Algemene Kerkvergadering gedien het, 
het ek dit nodig geag om die volgende sake na te vors en die resultate in hierdie studiestuk op te neem:

- $\quad$ redes vir die ontstaan van die klassieke formuliere;

- $\quad$ plek en tyd van die onstaan van die klassieke formuliere;

- die doel en funksie van formuliere;

- $\quad$ waarom nuwe en/of alternatiewe formuliere nodig is;

- $\quad$ kriteria waaraan formuliere moet voldoen;

- $\quad$ Bybelse en Reformatoriese perspektiewe op die ampte;

- $\quad$ besondere aspekte rakende die amp van dienaar van die Woord.

\section{NOODSAAKLIKHEID VAN FORMULIERE}

Formuliere speel in feitlik alle Reformatoriese Kerke 'n groot rol. In die meeste Reformatoriese Kerke word die bediening van die doop, die nagmaal, die bevestiging van ampsdraers en die huwelik voorafgegaan deur 'n formulier. Om antwoord te gee op die noodsaaklikheid, die vorm en inhoud van formuliere, word daar eers aandag geskenk aan die agtergrond wat aanleiding gegee het tot die ontstaan van die sogenaamde klassieke formuliere. Hierna sal daar gefokus word op die funksie van formuliere en die inhoud en vorm van die geloofsopvoeding van die huidige lidmate van die kerk.

\section{REDES VIR DIE ONTSTAAN VAN DIE KLASSIEKE FORMULIERE}

Die oorgang van "Rome naar Reformatie in gereformeerde zin" het onderrig in die Bybelse boodskap 'n noodsaaklikheid gemaak. Die gewone lidmaat het nie kennis en insig gehad in die Bybelse boodskap en die kerklike praktyk nie (Van der Aa 2000:41). Naas die Kategismus wou die Reformatore die formuliere in die besonder benut om die lidmate te onderrig in die Bybelse hoofsake. Die algemene tendense wat in die Rooms-Katolieke Kerk aan die orde van die dag was, het hierdie onderrig noodsaaklik gemaak. Die onderstaande afleidings kan gemaak word (kyk Beukes 1993:62; Pont 1978:153):

- $\quad$ Die Bybel was in Latyn geskryf en gevolglik kon die meeste lidmate dit nie lees nie.

- $\quad$ Die erediens is gewoonlik in Latyn gehou en die grootste gedeelte van die gemeente was net toeskouers. Die gewone lidmaat het onder andere nie self die sakramente gebruik nie en het gevolglik feitlik niks daarvan verstaan nie. 
- $\quad$ Van onderrig deur die ouers en die kerk in die Woord van God, die leer van die kerk en die praktyk van die kerk was daar feitlik nie sprake nie. Dit het hoofsaaklik deur die skole, indien wel, geskied.

- $\quad$ Die ampsbeskouing van die Rooms-Katolieke Kerk was anders as wat dit in die vroeë kerk die geval was. Die gewone lidmate het feitlik geen kennis gehad van wat die ampte behels nie. Volgens Lekkerkerker (1963:64) moes die formuliere veral dien om die teologie van die Reformasie in die regte perspektief te stel en om dit die "eiendom" van die lidmate wat saam met die kerkhervorming gegaan het, te maak. Die formuliere is veral gebruik om die Rooms-Katolieke teologie, hulle verstaan en gebruik van die sakramente en hulle beskouings van die ampte by die lidmate tuis te bring. Naas onderrig in die teologie van die kerk was dit vir die Reformatore belangrik om die ingrypende veranderinge in die kerklike praktyk vir die lidmate te verklaar en toe te pas. Dit was veral die formuliere vir die bevestiging van ampsdraers wat hier moontlik 'n groot funksie sou kon vervul.

Aan die ander kant is dit belangrik om daarop te let dat die formuliere nie in die eerste plek vir die Reformatore ' $n$ middel was om die lidmate te bind aan 'n nuwe kerklike dogma nie, maar aan die Woord van God, aan God self. Dit was 'n poging om die volk te "onderwijzen in de Schriften ... In het formulier wordt beleden wat de Schrift verkondigt" (Van der Aa 2000:64). Hoewel die formuliere sterk didakties ingeklee is, wou die die Reformatore nie net die volk daarmee onderrig nie. Die formuliere was bedoel om veral in die erediens gebruik te word (Pont 1993:3). As sodanig wou die Reformatore dit nie net gebruik om te leer nie, maar ook om te beleef, veral die grootheid van God se genade in die erediens. Die formuliere kan gesien word as integrerende deel van die erediens om die gelowiges na God toe te lei en om hulle toe te rus vir hulle dienswerk in die wêreld. Op grond hiervan het die formuliere nie net 'n didaktiese nie, maar ook 'n pastorale aanslag.

Het is wel treffend te merken hoe een mens in zijn nood van zonde, twijfel, zwakheid en angst gekend wordt. Juist deze geslagen mens wordt gedragen tot bij God, opdat die mens zich gesterkt mag weten in het gebruikt van de sacrament om Zijn leven te vervolgen. Didactiek staat pastoraat en liturgie niet in de weg, zij ondersteunt die veeleer.

(Van der Aa 2000:65)

Die Kerkhervorming het oor feitlik die "hele wêreld" plaasgevind. Dit is gedra deur bepaalde sentrale gedagtes waarvan Luther se 95 stellings die basis gevorm het. Dit het egter baie gou gebeur dat daar ten opsigte van sekere 


\section{'n Alternatiewe formulier vir die bevestiging van dienaars van die Woord}

aspekte nuanse verskille na vore gekom het, veral ten opsigte van die verstaan van die sakramente en die ampte. Die formulier sou gevolglik 'n baie belangrike middel wees om die eenheid in die "Hervormde" kerk te bewaar.

\section{PLEK EN TYD VAN ONTSTAAN}

Die Klassieke Formuliere is geheel en al die produk van die Reformasie en is deurdrenk van die teologie daarvan. Beide die doop- en die nagmaalformulier se oorsprong is die Palts waar 'n Nederlandse vlugtelinggemeente gevestig was (Lekkerkerker 1963:73; Van der Aa 2000:43; Pont 1993:2).

Pont (1993:1) is van oordeel dat veral die Rooms-Katolieke missaal gesien kan word as die basiese aanleidende oorsaak vir die ontstaan van die Reformatoriese formuliere. "In die Westerse kerk het die godsdiensoefening ontwikkel in die Rooms-Katolieke missaal, dit wil sê die boek met die 'formulier', die gebede en liedere van die Rooms-Katolieke mis." In die Middeleeue is die missaal deur feitlik al die Rooms-Katolieke Kerke gebruik. In 1570 het dit vaste vorm gekry en het verpligtend vir alle Rooms-Katolieke Kerke geword.

Die Rooms-Katolieke nagmaalbeskouings was waarskynlik een van die sake wat aanleiding tot die Reformasie gegee het. Die beginsels en standpunte van die Reformatore is opgeneem in hulle godsdiensordes waarvan die volgende die belangrikste is: Luther se Formula Missae van 1523 en sy Deutsche Messe van 1526, Zwingli se De canone missae epicheiresis van 1525, sy Action oder bruch des nachtmals in 1526 en sy Straatsburgse diensorde ook van 1526. Johannes Calvyn het met sy godsdiensordes van Straatsburg 1542 en Geneve 1545 in 'n groot mate konsolidasie bewerk tussen die verskillende Hervormers. Die genoemde ordes het enersyds die Rooms-Katolieke dwaling aangetoon en andersyds positiewe riglyne vir die Reformatoriese erediens gegee.

Datheen het die nagmaalformulier wat hy in die Palts aangetref het, vir dié gemeente vertaal. Vandaar is dit in die Nederlandse Hervormde Kerke algemeen aanvaar. Pont (1993:2) is van oordeel dat: "Die Paltz-

Nagmaalsformulier is op sy beurt 'n samevoeging van die Nagmaalsformulier van Geneve van Calvyn; die formulier van die Londonse vlugtelinggemeente en die Lutherse agenda van Wurtenberg van 1553 met hier en daar eie toevoegings van Datheen" (Kyk ook Lekkerkerker 1956:134).

Net soos die nagmaalformulier het die doopformulier ook sy oorsprong in die Palts (Lekkerkerker 1956:73; Van der Aa 2000:43). In die Kerkorde van die Palts in 1563 verskyn 'n volledige doopformulier. Dit is waarskynlik ook deur Datheen in Nederlands vertaal waar die invloed van Calvyn, A Lasco en Micron veral gesien kan word. 
Die huweliksformulier het waarskynlik net soos die reeds genoemde formuliere sy oorsprong in die Palts. Agter in die Psalmberyming van Datheen was gebede vir die erediens en formuliere vir die nagmaal, doop en huwelik. Hierdie diensboek van Datheen is vanaf 1568 in geheel deur feitlik al die Hervormde gemeentes in Nederland aanvaar (Lekkerkerker 1956:73).

Die oorsprong van die formuliere vir die bevestiging van ampsdraers is onbekend. Die sinode van Gravenhage maak die eerste melding daarvan as daar gepraat word van 'n "bevestiging naar het formulier" (Lekkerkerker 1956:107). Dit verskyn die eerste keer in gedrukte vorm agter in die Bybel by Jan Paadts Jacobzoon te Leiden in 1590. Dit toon ooreenkoms met beskrywings van die ampte van à Lasco en Micron wat reeds verskyn het. Verder het die sinodebesluite van Wezel 1568, Emden 1571, Dordt 1574 en 1578 'n beslissende rol in die vorming van die eindproduk gespeel (Lekkerkerker 1956:112). Pont (1981:20, 190) gee te kenne dat Calvyn se Ordonnances Ecclèsiastiques ook 'n bydrae in die vormgewing van die bevestigingsformuliere gelewer het en sy ekklesiologie asook ampsbeskouing word ook duidelik hierin gehoor.

\section{DOEL EN FUNKSIE VAN FORMULIERE}

Volgens Pont (1993:3) is "'n (f)ormulier ... 'n amptelike uiteensetting en onderwysing ten opsigte van die instelling en betekenis van bepaalde handelinge in die erediens." Die formuliere word hoofsaaklik in die erediens gebruik. As sodanig wil dit net soos die res van die erediens dien om ontmoeting tussen God en sy gemeente en die gelowiges onderling te bevorder (Beukes 1993:34). Dit funksioneer as verkondiging, veral saam met die sakramente, en dien so tot versterking van die erediensgangers se geloof. Die Reformatore het deurgaans betoog dat Woord en sakrament nie geskei mag word nie en dat die formuliere as sodanig, saam met die sakramente, noodsaaklike verkondiging is. By die formuliere vir die bevestiging van ampsdraers dien die formuliere in die besonder om aan die ampsdraers die oorsprong en funksie van die ampte te beskryf, as toerusting vir die ampsdraers wat bevestig word en die gemeente wat teenwoordig is. Die huweliksformulier spel kortliks aan die egpaar uit dat die huwelik ' $n$ instelling van God is en wat die man en vrou se verantwoordelikhede teenoor mekaar is.

Vanuit 'n ander hoek gesien kan die formuliere ook beskryf word as middele wat dien om die gemeentelede se betrokkenheid te bevorder. Die sakramente wat bedien word, raak ouers, dopelinge en elke gemeentelid. Enersyds gee dit vir hulle die sekerheid dat hulle aan die drie - enige God behoort en deel van sy kerk is en andersyds roep dit hulle op om soos God se 


\section{'n Alternatiewe formulier vir die bevestiging van dienaars van die Woord}

kinders te leef. Die formulier dien om hierdie besondere boodskap te kommunikeer en te help dat hulle nie net toeskouers by die bediening van die sakramente is nie, maar aktiewe deelnemers en deelgenote aan die verlossing deur Christus wat hier in die middelpunt staan. Net so dien die formuliere vir die bevestiging van die ampsdraers as middele om die ampsdraers en die lidmate se betrokkenheid by God se dienswerk in die wêreld te bevorder. Die formulier vir die bevestiging van die huwelik help weer met die bevordering van die egpaar se betrokkenheid bymekaar en vir mekaar.

Naas die regte deelname het die Reformatore die formuliere gesien as middele om te help met die regte verstaan van die sakramente, die ampte en die huwelik. As sodanig het dit naas die Kategismus en die prediking gedien as onderrig (Lekkerkerker 1963:81; Van der Aa 2000:64). Dit was eintlik kort preke of kategeselesse by elkeen van die ter sake sakramente, ampte of huwelik.

As kernagtige verklaring kan die formuliere ook gesien word as weergawe van 'n bepaalde Kerk se belydenis of verwoording van wat hy verstaan van die sakramente, die ampte en die huwelik.

Formuliere word opgestel of funksioneer binne 'n bepaalde kerk. As sodanig dien dit ook om die eenheid tussen die verskillende gemeentes uit te druk en in 'n sekere sin selfs te bevorder. As kerke gesamentlike formuliere opstel of benut, soos in die geval van die klassieke formuliere, dien dit die eenheid tussen daardie kerke. Dit het dus ook 'n ekumeniese funksie.

In die lig van bogenoemde kan Pont se definisie uitgebrei word en kan formuliere gesien word as: 'n Amptelike uiteensetting en onderwysing ten opsigte van 'n bepaalde handeling in die erediens met die oog op aktiewe deelname en eenheid.

\section{WAAROM NUWE EN/OF ALTERNATIEWE FORMULIERE?}

H H Barger het reeds in 1907 fel kritiek teen die klassieke formuliere uitgespreek: "Zij zijn zo lang. Ook zijn zij droog en koel van toon, niet bezielend" (Barger, in Lekkerkerker 1956:87). In 1956 was dit veral Lekkerkerker wat kritiek teen die klassieke formuliere uitgespreek het en in die jongste tyd Van der Aa (2000). In Suid-Afrika is feitlik al die gereformeerde kerke besig met die daarstel van nuwe en alternatiewe formuliere. Sedert die sestiger jare van die vorige eeu het dit 'n deurlopende proses in die Nederduitsch Hervormde Kerk van Afrika geword. Die enigste besware is nie alleen gerig teen die lengte en die taal as sodanig nie. Kritiek loop oor 'n baie breë linie. Die volgende kan genoem word: Die didakties aard van die klassieke formuliere spreek nie die postmoderne mens aan nie. Die 
postmoderne mens se ingesteldheid is van so 'n aard dat hy eerder aangespreek word deur 'n pastorale - akkomoderende styl as deur 'n didaktiese styl. Dit behoort daarom in die formuliere meer om die bevordering van deelname te gaan as koue didaktiese onderrig.

Die klassieke formuliere kan beskryf word as didaktiese formuliere waarin die gemeente grondig onderrig word met betrekking tot ' $n$ bepaalde handeling in die erediens. Hierdie breë onderrig, soos reeds aangetoon, was vanweë verskillende faktore tydens die Reformasie noodsaaklik. Die situasie het vandag egter so verander dat hierdie breë, grondige onderrig deur middel van 'n formulier nie meer nodig is nie. Daar kan na die volgende verwys word:

- $\quad$ Die kerk beskik in die belydenisskrifte en die kategeseboeke reeds oor duidelik geformuleerde en gesistematiseerde inhoude betreffende die leer van die Kerk oor die sakramente, die ampte en die huwelik wat in die formuliere ter sprake is. Dit is geskryf in die taal van die lidmate en toeganklik vir almal.

- $\quad$ Die kerk se kinders groei op in ouerhuise waarvan die ouers self in die kerk groot geword het - kinders wat daarom self deur die ouers onderrig is in die betekenis van die doop en die verantwoordelikheid wat dit meebring.

- $\quad$ Tydens die doopkategese word die doopouers onderrig oor die betekenis van die doop.

- $\quad$ Kinders word groot in die kerk waar hulle breedvoerig, vir ongeveer elf jaar, in die kategese onderrig word. Verder sit die meeste van hulle feitlik elke Sondag in die erediens en kom die onderrig van die kerk ook tot hulle tydens die pastorale besoeke van ampsdraers en lidmate.

- Die meeste ouderlinge en diakens het in die kerk grootgeword. Van kleins-af het hulle in die ouerhuise en vanaf die kansel gehoor wat die ampte se doel en funksie is. Hulle sien deurlopend hoe ampsdraers funksioneer. Voordat hulle bevestig word, vind daar ook nog grondige kerkraadkategese plaas.

- $\quad$ Op teologiese vlak, in die kerk se vergaderings en geskrifte, is daar voortdurende gesprek, studie en navorsing oor die sake wat in die formuliere ter sprake is. Feitlik elke predikant is daagliks met die inhoude daarvan besig. Al die predikante van die kerk het feitlik in al hulle studiejare met die sake wat in die formuliere ter sprake is, geworstel en dit het in mindere of meerdere mate in elke teologiese departement ter sprake gekom. Dit is veral in Dogmatiek, Kerkreg en Praktiese Teologie deurgetrap. 


\section{'n Alternatiewe formulier vir die bevestiging van dienaars van die Woord}

- $\quad$ Huwelikspare word groot met die huwelik rondom hulle. Hulle sien dit in die lewe van hulle ouers en het baie in die kategese en die erediens daarvan gehoor.

Mensinga sê tereg "dat sommige van de geciteerde bijbelteksten niet bewijzen, wat ze bewijzen moeten" (Mensinga, in Lekkerkerker 1956:87). Die Skrifgebruik in die formuliere is van 'n aard wat vandag nie meer algemeen aanvaarbaar is nie. Met betrekking tot die dienaars van die Woord kan onder andere verwys word na talle tekste wat gekies is om waarskynlik net te bevestig wat die Reformatore reeds geglo het (Lekkerkerker 1956:87). Die grofste voorbeelde is waarskynlik die volgende: Uit die instellingswoorde van die nagmaalformulier uit 1 Korintiërs 11:23-26 word sonder meer afgelei dat die dienaars van die Woord geroepe is om die sakramente te bedien. Uit 1 Timoteus 2:1, 2 word afgelei dat die dienaars van die Woord vir alle mense voorbidding moet doen en uit 1 Timoteus 5:17 dat die dienaars van die Woord moet preek. Reeds lankal is dit ook nie meer aanvaarbaar dat Handelinge 6 gebruik word om die instelling van die diakenamp te fundeer nie (Lekkerkerker 1971:120).

Die teologie wat in die Klassieke formuliere voorkom is die teologie van die Reformasie. Sekere aspekte van hierdie teologie word lankal anders deur sommige Gereformeerde teoloë geïnterpreteer. Daar word onder andere nie meer so maklik reglynig beweeg van besnydenis na doop, van pasga na nagmaal en van apostels na predikante nie (Van Niftrik 1961:338;

Lekkerkerker 1971:114). Die teologie van die formuliere behoort uitdrukking te gee aan die teologiese denke van die Reformasie met in agneming van die groei wat daar in die dogmatiek vanaf die sestiende eeu tot vandag plaasgevind het.

Die Reformasie het dit nodig gevind om die dwaalleer van die RoomsKatolieke Kerk vir die lidmate uit te wys. Die formuliere is veral ook vir hierdie doel benut. Vandag neem die lidmate van kleins-af daarvan kennis in die kategese, die erediens, huisbesoek, die ouerhuis en ander plekke. Tans is daar ander "gevare" op die pad van die gelowiges en is onderrig oor die Rooms-Katolieke dwaalleer veral nie meer deur middel van die formuliere so noodsaaklik nie.

In die klassieke formuliere kom verskeie aspekte rakende die ampte na vore wat die kerk vandag anders verstaan. In die klassieke formuliere word waarskynlik te maklik reglynig beweeg tussen apostels en herders en die huidige bedienaar van die Woord. Dit word op so 'n wyse gedoen dat steeds gepraat kan word van 'n "apostolische successie" (Lekkerkerker 1956:89). Verder word die ouderlingamp beperk tot geestelike versorging en die van die 
diaken tot die stoflike. Die ampsbeskouing, soos dit in die klassieke formuliere voorkom, berus waarskynlik op enkele tekste uit die Bybel en die beskouing dat die ampte slegs vir manlike persone toeganklik is. Grondige studie oor die ampte toon dat daar vandag ook ander beskouing oor die ampte bestaan en dat nuwe formulering wat pas by die nuwe verstaan, nodig geword het. Pelser (1990), onder andere, reken dat ons in die Nuwe Testament nie voorskrifte kry oor hoe die ampte se funksionering altyd daar behoort uit te sien nie. "Verloop van tyd, andersheid van situasie, verskil in kerkbegrip en dies meer was telkens verantwoordelik vir eiesoortige persepsies oor die bedieninge ... " (Pelser 1990:14).

Ek is persoonlik van oortuiging dat die kerk, of dan elke denominasie, vry is om sy bedieninge te orden soos hy dit in verantwoordelikheid vanuit die Skrif goed vind. Wat die Reformasie betref, was die "destydse gebruike" (Pont 1981:21) naas die Skrif medebepalend vir die inrigting van die ampte. Die kerk kan nie anders as om vandag opnuut te kyk na die wêreld waarin hy leef en ook sy ampte se funksionering só in te rig dat dit die saak van die koninkryk van God die beste sal dien nie. Hierdie nuwe besinning sal ook in die formuliere verwoord moet word.

Die skryf van formuliere is mensewerk. Dit is die mense van die kerk se verwoording van hulle besinning oor ' $n$ bepaalde handeling op ' $n$ bepaalde stadium van die kerk se geskiedenis. Dit bring mee dat formuliere nooit volmaak sal wees nie en dat die kerk ook nooit klaar sal kry met die skryf daarvan nie.

\section{KRITERIA WAARAAN FORMULIERE MOET VOLDOEN}

Uit die aard van die saak sal formuliere moet voldoen aan die funksie en doel waarvoor dit daar gestel word. Daar sal verder gelet moet word op die kritiek wat daar teen die huidige formuliere bestaan. In die lig van die voorafgaande sal die volgende waarskynlik belangrik wees vir die opstel van nuwe en of alternatiewe formuliere en dan in die besonder vir die bevestigings formulier van dienaars van die Woord:

- $\quad$ Kernagtige verwoording wat die betekenis van die betrokke handeling vir die deelnemers en aanwesige lidmate beskryf.

- $\quad$ Skrifgebruik volgens teenswoordig aanvaarbare hermeneutiese norme.

- $\quad$ Teologiese verwoording ooreenkomstig die huidige hantering van die belydenisskrifte van die kerk.

- Verwoording van die Hervormde Kerk se ekklesiologiese denke.

- $\quad$ Skriftuurlike sakraments-, amps- en huweliksbeskouing.

- $\quad$ Fokus op funksionele en effektiewe gebruik in die erediens. 
- Verstaanbare taalgebruik vir die lidmate van vandag.

- Pastorale aanslag.

\section{VERSKILLENDE BESKOUINGS OOR DIE AMPTE}

Gedurende die laaste aantal jare is daar baie navorsing gedoen oor die ampte in die algemeen en in die besonder oor die amp van dienaar van die Woord. Wat hier onder volg is slegs 'n klein seleksie uit die magdom van navorsing wat gedoen is, eintlik net 'n paar terloopse opmerkings.

\subsection{Ou Testamentiese perspektiewe}

Die Ou Testament ken nie ampte soos ons dit vandag ken nie. Dit is 'n veelkleurige boek wat oor 'n lang tydperk onder verskillende omstandighede ontstaan het. Dit bevat verskillende beskrywings vanuit verskillende invalshoeke en dit sou daarom te simplisties wees om te praat van ampte in die Ou Testament. Verskillende skrywers oordeel dat bepaalde aspekte wat in die Ou Testament genoem of hanteer word tog bruikbaar kan wees wanneer ons sou handel oor die ampte in ons huidige tydsgewrig. Prinsloo (1988:37) sê die volgende:

\footnotetext{
Ons moet wegkom van teksverse en eerder werk met breë teologiese riglyne. Teologiese riglyne wat die resultaat is van grondige eksegese waarin die historiese, literêre en teologiese konteks van die Ou Testament ernstig opgeneem word. Dit sou ons taak wees om in die lig van sulke teologiese riglyne en met inagneming van ons konkrete situasie die amp so in te klee dat dit tot welsyn van die kerk van Jesus Christus kan wees. Dit sou 'n soepelheid verleen, sodat daar nie 'n verstarring of ongesonde verampteliking van die amp plaasvind nie.
}

Kloppers (1988:21) plaas bepaalde gegewens vanuit die ebed JHWH figuur op die tafel wat volgens hom in hierdie verband bruikbaar kan wees. Verskillende middelaarsfigure en veral die ebed JHWH in die Ou Testament kan relevante gegewens bied as vanuit 'n Ou Testamentiese perspektief oor die ampte en veral die dienaar van die Woord iets gesê moet word. Volgens hom is die volgende riglyne in die hantering van hierdie gegewens egter van deurslaggewende belang:

- $\quad$ Die ontwikkelingslyne kan nie simplisties deurgetrek word na die Nuwe Testament en vandaar na vandag nie. Dit moet binne die eie tydsverband gedoen word. 
- $\quad$ Dat God as die vrymagtige hierdie "dienswerk" daarstel en ook daartoe roep, staan voorop. Daarom mag in die bepaling van ontwikkelingslyne nie so strak gehandel word dat dit voorskriftelik word nie. Ruimte moet gelaat word vir die wyse waarop die Here God deur sy Gees op 'n bepaalde tydstip die ampte in sy kerk wil laat funksioneer.

In die Ou Testament staan God se handelinge met die volk Israel in die middelpunt. Hierdie handelinge van God word gekenmerk deur sy handelinge met veral die profeet, priester en koning wat geroep word om as middelaarsfigure tussen Hom en die volk te funksioneer. As daar gekyk word na die persoon en die werk van die predikant, sou uit die koningskap, die priesterskap en die profetisme, waarskynlik heelwat gegewens geput kan word wat benut kan word vir die beskrywing van die dienaar van die Woord se funksionering vandag. Die besondere funksionering van die profetisme bied volgens Prinsloo (1988:36) waarskynlik die meeste materiaal wat benut kan word as daar vanuit 'n Ou Testamentiese perspektief gekyk word na die predikant in vandag se konkrete situasie.

Opsommmend kan die volgende breë teologiese riglyne getrek word met betrekking tot die profetisme soos ons dit in die Ou Testament aantref.

- Die Here roep die profete en bekwaam hulle om in sy diens te staan.

- Dit gaan nooit om die profetisme of die profeet as sodanig nie, maar om die verkondiging van die Here se boodskap. Die profeet sê altyd: So sê die Here. Om dit te kan sê, moet die profeet die wil van God ken.

- Die ware profete tree nie namens hulleself nie, maar namens die Here op.

- $\quad$ Die profete het 'n konkrete boodskap vir hulle tyd. Hulle verkondig ou waarhede op 'n nuwe aktuele manier. Die profete leef binne 'n bepaalde tradisie maar herinterpreteer dit vir hulle eie tyd.

- $\quad$ Die profete se boodskap is gerig tot alle lae van die volk en hulle boodskap raak alle fasette van die lewe. Hulle verkondig heil en oordeel.

- $\quad$ Die profete verkondig die Woord van die Here aan die hele volk, maar tree ook pastoraal met individue in gesprek.

- $\quad$ Om die boodskap van die Here so goed as moontlik uit te dra, maak die profete gebruik van alle moontlike kommunikasiemedia van hulle tyd. Hulle verkondig hulle boodskap met woord en daad. Nie net die profete se verkondiging is belangrik nie, maar ook hulle lewenswyse. 


\subsection{Nuwe-Testamentiese perspektiewe}

Versteeg (1998:71) het geskryf: "Bij wat het Nieuwe Testament ons zegt over het ambt is voortdurend voor ogen te houden, dat het Nieuwe Testament ons daarin niet een blauwdruk voor alle tijd geeft. Tegelijk is evenzeer voor ogen te houden, dat het Nieuwe Testament ons daarin wel een oriëntatiepunt voor alle tijden geeft." Van Eck en Pelser se hantering van die Nuwe Testament as oriëntasiepunt bied relevante gegewens vir die kerk en hierdie projek met betrekking tot die ampte in die algemeen en die amp van die Dienaar van die Woord in die besonder.

Die vroegste geloofgemeenskappe het bestaan of in terme van huisgemeentes of, indien 'n aantal huisgesinne saam 'n geloofsgemeenskap gevorm het, in terme van 'n fiktiewe huishouding na analogie van 'n gewone huishouding. Aan die hoof van hierdie huisgemeentes was die pater familias. Baie faktore het dit net nie moontlik gemaak dat iemand anders as hierdie familiehoof die leiding kon neem in die huisgemeente nie. Die Nuwe Testament maak gebruik van verskillende begrippe om die funksie en persoon van die pater familias te beskryf waar presbus/presbuteros, poimen, prohistamenos, oikonomos en episkopos (Van Eck 2003:1) van die belangrikste is.

Na deeglike navorsing oor genoemde begrippe kom van Eck tot die volgende gevolgtrekkings:

- $\quad$ Die pater familias het aan die hoof van die huisgemeentes gestaan. Hy moes die gemeente dien, lei en sorg dat goeie orde gehandhaaf word.

- $\quad$ As episkopos was die rol van die presbuteros om die gemeente te versorg soos 'n herder sy kudde versorg.

- $\quad$ As poimenos was die rol van die presbuteros om met medelye te waak oor die lede van sy huishouding/geloofgemeenskap, soos 'n vader oor sy kinders en soos 'n herder oor sy skape;

- $\quad$ As prohistamenos was die rol van die presbuteros om te versorg en te lei;

- $\quad$ As oikonomos was die rol van die presbuteros om op te tree as hoof van die geloofgemeenskap om as sodanig te lei en te bestuur en verder was dit sy verantwoordelikheid om die gawes uit te deel.

- $\quad$ As doulos moes die episkopos ook dien.

Naas die episkopoi/presbuteroi tref ons die diakonoi aan as leiersfigure in die eerste Christelike gemeente (Hand 6:1-4). As daar gelet word op hierdie persone se funksies kan die afleiding gemaak word dat diakonoi miskien net 
'n ander naam was vir die episkopoilpresbuteroi. Van Eck vat die funksies van die diakonoi soos volg saam:

- die versorging van behoeftiges (barmhartigheidsdiens);

- bystand aan gelowiges en alle mense in nood en ellende;

- die verkondiging van die evangelie.

Naas die apostels en in die periode direk na hulle was daar in die vroeë Christelike Kerk waarskynlik net een groep mense wat die leiding in die geloofgemeenskap geneem het. Hierdie leiers is episkopoi/presbuteroildiakonoi genoem. Hierdie "kerkleiers" het waarskynlik in breë trekke die werk gedoen wat ouderlinge (lerend en regerend) en diakens op 'n later stadium, volgens die Pastorale briewe, gedoen het.

Pelser (1990:1-18) se navorsing oor die bedieninge in die Nuwe Testament lei tot onder andere die volgende resultate:

- Die verskeidenheid met betrekking tot die bedieninge is so groot dat dit onmoontlik is om daaruit ' $n$ verteenwoordigende model of struktuur op te stel. Verloop van tyd, verskil in situasie, verskil in kerkbegrip en dies meer was telkens verantwoordelik vir eiesoortige persepsies oor die bedieninge. Die rykdom van die Bybel bied die moontlikheid vir verskillende ekklesiologiese modelle en daarvoor toepaslike bedieninge. "Die keuse van so 'n model sal vanselfsprekend bepaal word deur ' $n$ bepaalde denominasie se teologiese tradisie en eie verstaan van wat kerk in die lig van die Skrif is en behoort te wees. Die enigste werklike grondvereiste en kriterium is die verkondiging van die evangelie" (Pelser 1990:15).

- Paulus gebruik verskillende metafore om die kerk te beskryf. Pelser is van mening dat die bedieninge se bestaan en funksionering vir Paulus in die liggaammetafoor gefundeer is. Die hele liggaam is deur die Gees deurdrenk (1 Kor 12:13) en elke gemeentelid het 'n garisma van die Gees ontvang (1 Kor 7:7; 12:7, 11). "Elke lid is dus in 'n sekere sin 'n charismatiker" (Pelser 1990:15). Al die lede het gawes ontvang. Die verskillende lede het egter verskillende funksies en verrig daarom verskillende dienste (Rom 12:4;1; 1 Kor 12:4 vv). Daar is ook nie ' $n$ belangriker of minder belangrike funksie of garisma nie. Al die lede is ewe belangrik en ewe onontbeerlik (Rom 12:3; 1 Kor 12:14-26). By Paulus is daar nie sprake van ' $\mathrm{n}$ rangorde van dienste nie. "Al die bedieninge staan in verband met en verrig ' $n$ funksie met betrekking tot die sentrale bediening, naamlik die verkondiging van die evangelie, en 
deur middel hiervan die opbou van die gemeente in die geloof" (Pelser 1990:15).

- Die klem op die garismatiese en liggaammetafoor beteken hoegenaamd nie dat die gemeentelike funksionering maar onordelik kan wees nie. Paulus het volgens

1 Korintiërs 13 en 14 juis geoordeel dat met die oog op die orde bepaalde bedieninge in 'n sekere sin afgebakend moet funksioneer. So pleit hy veral vir die voorrang van die "verkondiging." Pelser (1990:16) stel dit soos volg:

Inderdaad sal ons met die een sentrale lewensveranderende doelwit, naamlik die verkondiging, steeds voor oë, nie kan toelaat dat hierdie doelwit as gevolg van ongereeldheid, ontoegerustheid, ongestruk-tureerdheid en onordelikheid, juis nie bereik word nie. Daar moet dus voortdurend na die ordelikste en mees verantwoorde bediening in elke vorm of gestalte van verkondiging gestreef word. Maar tegelyk moet daar met nougesetheid gewaak word dat struktuur of die model nie die Gees dwarsboom en die gemeente tot 'n Gees-lose lekedom laat verarm nie.

Dit gebeur veral as die garisma wat lidmate ontvang het, onbenut gelaat word of verdring word deur 'n onveranderlike vasstaande vorm of struktuur.

\subsection{Historiese perspektiewe}

Beide van 't Spijker (1988:111-127) en Rossouw (1988:128-149) oordeel dat die Reformatoriese ampsbeskouing hoofsaaklik gegrond is op die beskouings van Bucer en Calvyn en kom veral tot uitdrukking in die Nederlandse Geloofbelydenis (Artikels 30-32) en die Klassieke Formuliere uit die vyftiende eeu (kyk in hierdie verband veral ook Pont 1981).

Hulle is van mening dat Bucer en Calvyn se ampsbeskouings uitgaan van Christus as profeet, priester en koning en verder dat hierdie Reformatore se teologiese uitgangspunte van die wese van ware kerkwees naamlik suiwer verkondiging van die Woord, regte bediening van die sakramente en toepassing van die kerklike tug, (Nederlandse Geloofbelydenis artikel 29) die basis vir hulle ampsbeskouing, gevorm het. Hoewel dit op die oog af by die Reformatore lyk of die dienswerk van die gelowiges geheel en al verslind word deur die ampte, of daar geen ruimte is vir die apostolaat nie en of die bepaalde ampte gesien word as 'n ewige onveranderlike instelling, is dit hoegenaamd nie die geval nie.

Met betrekking tot die onveranderlike, vasstaande ampte word die volgende onder andere van Bucer gesê: 
Bucer kan het viertal reduceren tot een tweetal, naamlik dat van de ouderling en dat van de diaken. Maar hij kan het ook uitbreiden tot een zevental, dat hij in de vroege kerk meende aan te treffen, kortom hij kan spreken van het ene ministerium, dat zich specificeert naar gelang het nodig is. Maar altijd is de verbijzondering van het ene ambt in vele ambten vrucht van de Geest, die er op gericht zijn om ons deel te geven aan Christus zelf. $\mathrm{Zij}$ hebben tot doel het opbouw van het Lichaam van Christus.

(Van 't Spijker, in Rossouw 1988:117)

Die bediening van die Woord het vir die Reformatore in die middelpunt gestaan met die oog op die gemeente se deelhê aan Christus en mekaar. Die kerk was verder vir hulle deur en deur 'n liefdesgemeenskap, 'n diakonale gemeenskap wat mekaar in geestelike dinge "maar ook met de dingen die tot het dagelijks leven noodzakelijk is" bygestaan het (van 't Spijker, in Rossouw 1988:118).

Hoewel die klem by die Reformatore swaar op die ampte val, is die dienswerk van die gelowiges nooit uitgesluit nie. "Ook hier treft ons de gedachte van het priesterschap van alle gelovigen: iedere christen is geroepen om zielzorg uit te oefen. Alle leden van het Lichaam van Christus moeten elkaar helpen en raad geven. Men ziet dat het bijzondere ambt geenzins het ambt van alle gelovigen verdringt. Het omgekeerde is veeleer waar: de ambten moeten het Lichaam zelf stimuleren." Bucer het die ampte gesien as die organe waarmee Christus in die gemeente gewerk het, en vanuit die gemeente in die hele gemeenskap sodat die hele gemeenskap uiteindelik "een Rijk van Christus worden" (Van 't Spijker, in Rossouw 1988:119).

Naas die prediking en die onderrig (kategese van kinders en volwassenes) het die pastorale versorging ook 'n besondere plek ingeneem. Met die oog hierop het Bucer twaalf ouderlinge gehad wat saam met hom hulle toegelê het op die "herderlijke zorg" (Van 't Spijker, in Rossouw 1988:123). Reeds vanaf 1550 het Calvyn die beginsel ingestel dat die bedienaar van die Woord (herder) jaarliks 'n besoek aan al die gesinne van die gemeente moet bring. Hierdie besoek moet die karakter van onderwysing, vertroosting, vermaning en geloofsopbou dra (Rossouw 1988:144).

Opsommend kry ons die volgende beeld van die ampte en in die besonder van dienaar van die Woord uit die Nederlandse Geloofbelydenis en die bevestigingsformulier. Die Nederlandse Geloofbelydenis artikels is nie baie breedsprakig oor die ampte nie. Dit vermeld dat met die oog op geestelike bestuurswyse die ampte van dienaars van die Woord, ouderlinge en diakens gegee is. Hierdie ampsdraers moet betroubare persone wees wat 


\section{'n Alternatiewe formulier vir die bevestiging van dienaars van die Woord}

voldoen aan die vereistes soos gestel in 1 Timoteus 3. Die formuliere uit dieselfde tydperk maak melding van drie ampte: dienaars van die Woord, ouderlinge en diakens. Met die oog op die versameling van 'n gemeente uit die hele mensegeslag het God volgens Efesiërs 4:11-12 verskillende ampte gegee om die gelowiges toe te rus vir hulle diens in die wêreld en die opbou van die gemeente. Uit genoemde verse kan afgelei word dat Christus die amp van herder en leraar ingestel het. Hierdie ampsdraers moet die kudde lei, beskerm en regeer. Die besondere weiding waarmee die kudde versorg moet word is die verkondiging van die Woord. Verder beskryf die Formulier in detail die werk van die predikant as:

- $\quad$ Die Woord grondig te verkondig deur te preek, onderrig te gee, te vermaan en te vertroos (1 Tim 5:17; Rom 12:6, 2; Tim 2:15; Tit 1:9; Hand 20:20; 1 Kor 14:3).

- $\quad$ Voor te gaan in gebed vir alle mense (Hand 6:4; 1 Tim 2:1, 2).

- $\quad$ Die sakramente naamlik die doop (Matt 28:19) en die nagmaal (1 Kor 11:23-26) gereeld te bedien.

- $\quad$ Die gemeente te regeer sodat alles in die gemeente ordelik verloop en almal hulle volgens die Woord gedra (Matt 18:18; 1 Tim3:4, 5; Tit 1:7).

In die Klassieke Formulier self word nie baie gesê van die lewe van die dienaar van die Woord nie, wel in die vermanende gedeelte. Hier word vir die dienaars van die Woord gesê hulle moet besef hulle is geroepenes van God. Hulle amp is 'n gawe van God. Trouens hierdie amp is absoluut noodsaaklik, omdat mense daardeur tot redding gebring word. Hulle moet hulleself oppas deur te let op hulle lewe en hulle leer. Hulle moet Christus liefhê en 'n goeie voorbeeld vir alle mense stel.

\subsection{Praktiese Teologiese tendense}

Op Prakties Teologiese vlak is daar die laaste aantal jare ook baie navorsing oor die ampte gedoen. In Prakties Teologiese kringe word deesdae eerder van bedieninge as ampte gepraat.

Na deeglike bestudering van relevante gegewens uit die Ou Testament, Nuwe Testament en die Reformasie kom Hendriks (1990:38) tot die gevolgterekking dat die Reformatore van 'n bepaalde denkskema uitgegaan het naamlik die "munus triplex" en verder het kulturele-sosiologiese faktore daartoe gelei dat 'n hiërargies georiënteerde ampstruktuur ontwikkel het wat tot vandag nog by ons in praktyk is. Hendriks pleit vir 'n struktuur waar nie 'n amp nie maar diens die vertrekpunt is. Uitgaande van die dienskarakter staan die gelowiges met hulle koinonia en hulle getuienis in die wêreld in die 
middelpunt en nie die ampte nie. Hier sal tog weer sprake wees van voorlopers in die sin van 'n leidinggewende en lerend-toerustende bediening. Dit is volgens Hendriks nie 'n nuwe bloudruk nie, maar slegs 'n struktuur vir die huidige tydsgewrig.

Heyns (1990:61-72) sluit in 'n groot mate by Hendriks aan en pleit ook vir 'n dienswerk model. Elke gemeente behoort volgens hom te soek na 'n model om die gemeentelede te lei tot geestelike volwassenheid, dinamiese betrokkenheid, ondernemende selfstandigheid en persoonlike verantwoordelikheid. Dit alles moet geskied in geloofsafhanklikheid onder leiding van die Heilige Gees. In so 'n struktuur sal nie in die eerste plek gevra word na watter ampte nodig is nie, maar na watter funksies verrig moet word. Met die oog op die funksies sal daar na mense gesoek moet word wat die nodige gawes het en verdere toerusting sal dan moet plaasvind.

Pieterse (1990:22-39), Dreyer (1995:260-261 \& 1996:179-189), Coetzee (2001:271-288), Beukes (1997:670-690) en ander het in hulle navorsing oor die ampte hulle vertrekpunt geneem by die vraag wat die kerk se funksies in die wêreld is. Daar kan maklik vasgesteek word by die Reformatoriese kenmerke van die ware kerk (Nederlandse Geloofbelydenis). Dit sou ons weer nie verder bring as regte preke, regte sakramentsbediening en toepassing van die tug nie. As verantwoordelike teoloë sal ons egter moet gaan kyk na die kerk soos ons Hom aantref in die Nuwe Testament. Pieterse (1990:28-32) beperk die funksies van die kerk tot kerugma, koinonia en diakonia. Hierdie funksies wil hy grootliks tot hulle reg laat kom in en rondom die erediens en verder in die funksionering van die gemeente as liggaamsmodel in groepe. In hierdie model sal die dienaar van die Woord veral die funksie hê van preek, toerus en leiding gee. Uit veral die eerste hoofstukke van Handelinge blyk dat die kerk breër funksies het naamlik: lofprysing, verkondiging, barmhartigheidsdiens, onderlinge koinonia en die apostolaat. As dit die kern van kerkwees is, sal die predikant toegerus moet word om leiding te neem met die begeleiding van die gemeentelede dat elkeen God prys, onderling vir mekaar omgee, mense in nood help en bystaan en met woord en daad van God getuie in die wêreld is.

\subsection{Die Nederduitsch Hervormde Kerk vandag}

Die Nederduitsch Hervormde Kerk van Afrika sien die funksies van die predikant nog basies dieselfde as in die tyd van die Reformasie. Die Kerkorde (2.1.5 bladsy 7) sê dat die predikant iemand is wat die Woord van die Here voortdurend bestudeer en dienswerk in die gemeente doen deur: 
- Die Woord te verkondig en die sakramente te bedien.

- $\quad$ Eredienste te lei.

- $\quad$ Die gemeente herderlik te versorg.

- Kategetiese onderrig te gee.

- $\quad$ Die evangelie uit te dra na alle mense.

- $\quad$ Deel te neem aan die opsigtaak.

- $\quad$ Ampsdraers en lidmate toe rus vir hulle dienswerk in die wêreld.

In die ordinansies word die taak van die predikant egter breër en ook in konteks met die werk van die ouderling, diaken en kerkraad gesien. So word onder andere gesê dat die predikant verantwoordelik is vir die opsig en tug saam met die ouderlinge, saam met die diakens verantwoordelik vir die versorging van hulpbehoewendes en sien saam met die kerkraad om na die stoflike belange van die gemeente (Ordinansies 2.1.5, xvi, xvii, xviii bl 23).

\section{GEVOLGTREKKINGS}

Die huidige konteks waarin ons leef vra nuwe aanpassings met betrekking tot die ampte. In die lig van die voorafgaande studie is dit duidelik dat dit nie in die eerste instansie in die kerk behoort te gaan oor die instandhouding van bepaalde ampte nie, maar dat eerder gevra sal word hoe die kerk in die lig van die huidige omstandighede sy funksies kan laat realiseer. Primêr is dit sy funksie om Jesus Christus te verkondig (Pelser 1990) of breër gesien om die evangelie te verkondig, barmhartigheidsdiens te verrig en om leiding te gee aan die aktiwiteite van die gemeente. Nog breër gesien: om die gelowiges te begelei om God te verheerlik (aanbid), die Woord te verkondig, barmhartigheidsdiens te bewys, onderling vir mekaar om te gee en getuie in die wêreld te wees (Coetzee 2001). Aangesien baie minder mense vandag beskikbaar is om in die ampte te dien, sal die klem sterker moet val op die dienswerk van die gelowiges en sal noodwendig in die meeste gemeentes met baie minder ouderlinge en diakens gewerk moet word.

As die gelowiges behoorlik toegerus word om hulle dienswerk te doen, sal dit in elk geval nie meer nodig wees om met ' $n$ horde ampsdraers te werk nie. Die gebrek aan fondse gaan noodwendig daartoe lei dat baie gemeentes net 'n deelsorg - predikant sal hê. Die geweldige maatskaplike nood van ons tyd en die hunkering van mense na werklike koinonia sal meebring dat ons nie langer die klem eensydig sal kan plaas op die bediening van die Woord as synde, vir baie, die enigste werklike taak van die predikant nie. Die predikant sal self meer as ooit vir mense moet omgee en die lidmate leer om vir mekaar 
en alle ander mense om te gee. Die funksionering in groepe sal hier veral van deurslaggewende belang wees. Die onbetrokkenheid van ouers, enkel ouerskap, pornografie, vigs en ander bedreiginge, sal ook daartoe lei dat predikante meer aandag sal moet gee aan die toerusting van ouers, kategete en eie betrokkenheid by die kategese. Die geweldige sosiale probleme sal die predikant ook verder dwing om nie meer net prediker en kategeet te wees nie, maar in gelyke mate ook pastor.

In die lig van die voorafgaande het dit dringend noodsaaklik geword om 'n nuwe formulier vir die bevestiging van dienaars van die woord op die tafel te plaas.

\section{NUWE VOORGESTELDE FORMULIER}

Gemeente van ons Here, Jesus Christus

God het deur Jesus Christus verlossing vir die wêreld gebring. Deur die verkondiging van die evangelie en die werking van die Gees roep Hy mense om hierdie verlossing hulle eie te maak deur in Hom te glo en deel van sy kerk te word.

Aan almal wat tot geloof kom, gee God sy Gees om hulle te lei, te versorg en toe te rus vir dienswerk in sy kerk en in die wêreld. Vir hierdie diens rus die Gees alle gelowiges toe met 'n verskeidenheid gawes, maar Hy roep ook gelowiges om besondere dienswerk te doen soos die van predikant, ouderling en diaken.

Soos Jesus Christus, moet predikante hulle dienswerk nederig, toegewyd, en met liefde en oorgawe doen. Hulle word deur God geroep om in sy diens te staan en met sy Woord in die gemeente en die wêreld te werk. Dit is die predikante se werk om saam met die ouderlinge en diakens die gemeente in die geloof toe te rus, te lei en te versorg. Dit doen hulle deur die Woord te verkondig, die sakramente te bedien, voorbidding te doen en soos goeie herders, opsig te hou oor die gelowiges wat aan hulle toevertrou is en om hulle in hulle nood by te staan. So word die gemeente toegerus en gelei tot 'n lewe van lofprysing, aanbidding, danksegging, onderlinge gemeenskap, barmhartigheid en getuienis van Christus in die wêreld.

Die werk van predikante vind veral tydens die erediens, kategese en pastorale versorging plaas. Verder is hulle saam met die ouderlinge verantwoordelik vir die bestuur van die gemeente en saam met die diakens vir die barmhartigheidsdiens. 
Hierdie dienswerk kan alleen met vrug gedoen word indien die predikant 'n lewende verhouding met God het, self ' $n$ voorbeeld is van die geloofslewe wat sy/hy verkondig en steeds sorg dat sy/hy goed toegerus is vir hulle werk.

Geliefde suster/broer $\mathrm{N} \mathrm{u}$ is na hierdie gemeente beroep om die dienswerk wat aan $u$ voorgehou is te doen. Voordat $u$ as dienaar van die Woord bevestig kan word, moet u eerlik op die volgende vrae antwoord:

- Ten eerste: Glo u dat u wettig deur die gemeente van God en daarom deur God self tot hierdie diens geroep is?

- Ten tweede: Glo u dat die Ou en Nuwe Testament die Woord van God is en dat dit die boodskap van verlossing volkome verkondig, en verwerp u alles wat daarmee in stryd is?

- Ten derde: Beloof $\mathrm{u}$ om hierdie werk getrou en met oorgawe te doen en te leef soos God in sy Woord van $u$ verwag? Sal u die Christelike vermaning en dissipline van die kerk aanvaar indien u die werk nie doen soos $u$ beloof het nie?

Hierop moet sy/hy antwoord: Ja

(Al die teenwoordige dienaars van die Woord word nou na vore geroep om deel te neem aan die handoplegging of die gee van die regterhand van gemeenskap. Handoplegging vind plaas wanneer iemand georden word as predikant terwyl die hand van gemeenskap gegee word vir hulle wat al voorheen gedien het.

Tydens die ordening of die gee van die hand van gemeenskap word die volgende gesê:)

God ons hemelse Vader wat $u$ tot hierdie diens geroep het, sal $u$ deur sy Gees toerus, $u$ versterk en $u$ so in $u$ bediening lei dat $u$ daarin verantwoordelik en vrugbaar kan werk. So sal u deur u bediening die Naam van God groot maak en sal God deur u die heerskappy van sy Seun, Jesus Christus, in die wêreld uitbrei. Amen.

Daarna moet die dienaar van die kansel af die bevestigde dienaar en die hele gemeente soos volg toespreek:

Geliefde suster/broer en mededienaar in Christus: $U$ moet God liefhê en op Hom vertrou. Verryk u geloofslewe voortdurend en bid 
God om $u$ daarin te help. Sien om na u self, u huisgesin en almal wat die Here onder $u$ sorg geplaas het. Doen $u$ werk getrou en wees 'n voorbeeld vir die hele gemeente wat Jesus Christus deur sy bloed verkry het en wat deur die Heilige Gees onder u sorg gestel is.

En u, gemeente, neem u predikant met 'n oop hart aan. Behandel haar/hom met liefde en respek want God gebruik haar/hom om u na Hom toe te lei. Bid gedurig vir haar/hom en werk saam om die evangelie in die wêreld uit te dra.

Omdat ons nie self hiertoe in staat is nie, laat ons tot God bid Barmhartige God en Vader, ons dank $U$ dat $U$ self $u$ kerk instand hou. Dankie dat $U$ vir hierdie gemeente 'n predikant gegee het. Gee aan haar/hom die genade, die krag en die insig om haar/sy werk in die gemeente en die wêreld met oorgawe en na die beste van haar/sy vermoë te doen. Voorsien ook genadiglik elke dag in haar/sy en haar/sy gesin se behoeftes sodat hulle hulle werk sonder belemmering kan doen. Gee vir u gemeente die genade om haar/hom te erken as u gestuurde en om met haar/hom saam te werk tot u eer.

Ons vra dit in die naam van Jesus Christus, ons Here.

\section{Amen}

\section{Literatuurverwysings}

Beukes, M J du P 1993. Erediens, I. Pretoria: Kital.

Beukes, M J du P 1994. Erediens, II. Pretoria: Kital.

Beukes, M J duP 1997. Kerkleiding in die een en twintigste eeu. HTS 53, 670-690.

Coetzee, J J 2001. Die erediens as 'n dinamiese ontmoetingsgebeurtenis tussen God en gemeente, 271-287. Ongepubliseerde Agenda vir die $66^{\mathrm{e}}$ Algemene Kerkvergadering van die Nederduitsch Hervormde Kerk van Afrika.

Dreyer, T F J 1995. Praktiese Teologie as kommunikatiewe handelingsteorie. HTS 51, 260-261. (Boekbespreking.)

Dreyer, T F J 1996. Praktiese kerkwees in die nuwe Suid-Afrika. HTS 52, 179-189.

Hendriks, H J 1990. Bediening in en deur die gemeente: 'n Prakties-teologiese basisteorie. Praktiese Teologie in Suid-Afrika, 5, 19-42. Pretoria: V \& R Drukkery.

Heyns, L M 1990. Bedieninge in die gemeente: Praktykmodelle. Praktiese Teologie in Suid-Afrika, 5, 61-72. Pretoria: V \& R Drukkery.

Kloppers, M H O 1988. Die ontwikkeling van die amp in die Ou Testament. Gereformeerde ampsbediening, in Rossouw, P J, 9-23. Pretoria: NG Kerkboekhandel. 
Lekkerkerker, A F N 1956. Kanttekeningen bij het Hervormde dienstboek iv, openbare belijdenis, opzicht en tucht, ambt en bediening. Gravenhage: Boekencentrum.

Lekkerkerker, A F N 1963. Gij zijt gedoopt. Baarn: Bosch en Keuning N.V.

Lekkerkerker, A F N 1971. Oorsprong en funktie van het ambt. Gravenhage: Boekencentrum.

Nederlandse Geloofbelydenis, artikel 30 en 31. Diensboek Nederduitsch Hervormde Kerk van Afrika, 128-129, in opdrag van die Algemene Kerkvergadering 1995, Pretoria: Kital.

Nederduitsch Hervormde Kerk van Afrika 1997. Formulier vir die bevestiging van die dienaars van die Goddelike Woord. Diensboek, 75-79, in opdrag van die Algemene Kerkvergadering 1995. Pretoria: Kital.

Nederduitsch Hervormde Kerk van Afrika 2001. Kerkorde van die Nederduitsch Hervormde Kerk van Afrika gewysig volgens die besluite van die 65ste Algemene Kerkvergadering.

Pelser, G M M 1990. Die bedieninge in die Nuwe Testament: 'n Ondersoek na historiese wording en prinsipiële regverdigbaarheid. Praktiese Teologie in Suid-Afrika 5(1), 1-18.

Pieterse, H J C 1990. 'n Erediens: Uitsig op die gemeente, in Smuts, A J, Vos, C J A \& Nel, M (reds), Gesprek oor die erediens: Teologiese huldigingsbundel aan professor A C Barnard, 22-39. Pretoria: NG Kerkboekhandel.

Pont, A D 1978. Kerkgeskiedenis: 'n Oorsig van die Algemene Kerkgeskiedenis en die geskiedenis van die Nederduitsch Hervormde Kerk van Afrika, opgestel ten dienste van die kategese van die Kerk. Pretoria: HAUM.

Pont, A D 1981. Die historiese agtergrond van ons kerklike reg, akademiese handboeke, Deel 1. Pretoria: HAUM.

Pont, A D 1993. Die doel en funksie van 'n formulier. Memorandum vir die Raad van Belydenis en Liturgiese geskrifte van die Nederduitsch Hervormde Kerk van Afrika. Ongepubliseerde werkstuk, Nederduitsch Hervormde Kerk.

Prinsloo, W S 1988. Die funksionering van die "amp" in die Ou Testament: Die sogenaamde klassieke profete in Rossouw, P J (red), Gereformeerde ampsbediening, 24-39. Pretoria: NG Kerkboekhandel.

Rossouw, P J (red) 1988. Aspekte van ampsbeskouing van Calvyn, in Gereformeerde ampsbediening, 128-149. Pretoria: NG Kerkboekhandel.

Van der Aa, W P 2000. Ik doop u ... de heilige doop in de liturgie, in Van der Velden, M J G, Van der AA, W P \& de Bie, H J, Als wij samenkomen, liturgie in de gereformeerde traditie. Zoetermeer: Boekencentrum.

Van Eck, E 2003. Alternatiewe formulier vir die bevestiging van ouderlinge Agtergrond. Ongepubliseerde werkstuk, Nederduitsch Hervormde Kerk.

Van Niftrik, G C 1961. Kleine Dogmatiek. Nijkerk: Callenbach.

Van 't Spijker, W 1988. De ambten bij Martin Bucer, in Rossouw, P J (red), Gereformeerde ampsbediening, 109-149. Pretoria: NG Kerkboekhandel.

Versteeg, J P 1988. Het karakter van het ambt volgens Efeziërs 4:7-16, in Rossouw, P J (red), Gereformeerde ampsbediening, 49-74. Pretoria: NG Kerkboekhandel. 